\title{
NiKI DERLUKIEWICZ
}

Wroclaw University of Economics, Poland

ANNA MEMPEL-ŚNIEŻYK

Wroclaw University of Economics, Poland

TOMASZ PILEWICZ

Warsaw School of Economics, Poland

\section{MaŁgorzata Zdon-KorzeniowsKA}

Pedagogical University of Cracow, Poland

\section{Investment Offer as an Expression of Marketing Orientation of Polish Local Governments in the Context of their Investment Attractiveness}

\begin{abstract}
The marketing concept of the functioning of territorial units is well-known today, both in the literature of the subject and in practice, although the activities undertaken vary in their intensity and scope. The expressions of marketing thinking and actions are, among other things, activities undertaken by local governments in the area of shaping the offer of a territorial unit. In our research, we focused on the territorial investment offer of the Polish local regions (NUTS 5), as well as actions taken by local governments as the entities with the most real opportunities for shaping this offer. The main goal of our research was the exploration of market orientation (MO) and investment offer (IO) in the practice of local governments, and then an attempt to link the undertaken actions with their potential investment attractiveness (PAI). The conclusions contained in this article are based on research conducted on a random sample of 277 Polish local regions with the use of three research methods: electronic audit of the official web portals of local regions, the mystery stakeholder, and an electronic survey sent to the official administrative representatives of the local regions in the sample.The conducted research shows that Polish local governments are slowly adopting MO, increasingly identifying their customers (including investors) and knowingly providing the expected benefits. As part of the conducted research a wide collection of good practices was developed in the area of shaping the investment offer and marketing approach which should be promoted and discussed.
\end{abstract}

Keywords: investment attractiveness; investment offer; local government; local regions; marketing orientation

Received: 18 December 2017

Accepted: 10 July 2018

\section{Suggested citation:}

Derlukiewicz, N., Mempel-Śnieżyk, A., Pilewicz, T., Zdon-Korzeniowska, M. (2018). Investment Offer as an Expression of Marketing Orientation of Polish Local Governments in the Context of their Investment Attractiveness. Prace Komisji Geografii Przemysłu Polskiego Towarzystwa Geograficznego [Studies of the Industrial Geography Commission of the Polish Geographical Society], 32(3), 98-115. https://doi. org/10.24917/20801653.323.6

\section{INTRODUCTION}

In the context of globalization, competitive pressure is rising "not only on producers of market goods but also the quality of spatial-economic environments in which the producers operate" (Markowski, 2006: 89). A specific market is created, where certain 
administrative units compete for capital and customers. Territorial units are forced to prove their meaning also in market terms (Kotler, Rein, Haider, 1999). To win this competitive game they must demonstrate entrepreneurship and knowledge of market rules. They must be aware of the opportunities for development, and have the courage, but also the knowledge to use them. The need to professionalise territorial management and boost its development, as a response to the challenges of global economy, can be met by the concept of territorial marketing. It is based on an attempt to adapt the concept of sales and management developed for typical private sector products to the public sector (Markowski 1999).

According to W. Kuźniar (2013: 9), the success of a territorial unit is largely conditioned by the adoption and implementation of a marketing orientation aimed at meeting the needs of the current and future recipients of the territorial offer (understood as a set of utilities offered in a given area to interested groups of customers - residents, tourists, investors, etc., whose coordinator and animator are the authorities of the given territorial unit). Moreover, the adoption of marketing orientation by local governments is an expression of their entrepreneurial attitude (EA).

In the paper we tried to answer the question whether local governments' (NUTS 5) activities related to investment offer (IO) and marketing orientation (MO) corresponds with their potential investment attractiveness. To this end, it is worth to refer to investment attractiveness and explain that in the paper is accepted definition of Godlewska-Majkowska (2011: 4), as the ability to meet the expectations of investors considering investing in defined investment location and the conducted research refer to the index of potential investment attractiveness (PAI).

In the article we use two terms: local region and local government. Local regions are defined as spatial units at the NUTS 5 level (official hierarchical spatial territory division system within European Union), which are also known as locoregions. In Poland they are represented by communes, in Germany and Austria by Gemeinden, in Denmark by sogne, in Portugal by freugesias, and in Italy by comuni. By local government in our research we refer to formal authorities of NUTS 5 level units which are represented by public sector managers acting on behalf and for the public good of local communities living and working in local regions.

The importance of local regions as a reference point to research phenomena is reflected in the subject literature. Thus, authors decided to adopt the NUTS 5 level territorial unit, according to the classification system of spatial hierarchy in the European Union, as a basic spatial unit of analysis in the research. In Poland, the primary territorial units, in administrative terms, are represented by 2479 local regions called communes (Central Statistical Office of Poland, 2016). These types of local regions in Poland constitute the smallest self-government units, that are institutionally the closest to living and working communities.

In context of the research sampling frame, the authors used population of all local regions in Poland and performed stratified random sampling. The authors had intended to link explored activities of local regions with their potential investment attractiveness. Therefore, the indicator of potential investment attractiveness (PAI) of local regions was used to define subpopulations constituting the base for stratification within the sampling frame. The indicator in question was developed in the Warsaw School of Economics by a team of researchers. The methodology of its calculation has been thoroughly described in the subject literature (e.g. Godlewska-Majkowska, 2011; 
2013). According to this methodology, the level of potential investment attractiveness of a given spatial unit is based on a number of sub-indices, aggregated in the so-called microclimates. There are 5 microclimates calculated to determine the level of potential investment attractiveness of a spatial unit: human resources, technical infrastructure, social infrastructure, market, and administration. The sub-indices are based on quantitative data collected by the Central Statistical Office of Poland. Therefore, they are standardised and comparable among every local territorial unit in the country. Consequently, the degree of variation in the average level of the total potential investment attractiveness, based on these microclimates, is presented by a synthetic indicator of the potential investment attractiveness (PAI). Thus, all the local regions in Poland can be classified into 6 classes of the total potential investment attractiveness, ranging from the most (class A) to the least attractive (class F). In our paper we used the synthetic PAI index based on public statistics of 31 December 2014. Stratification in the research sample selection reflected the potential investment attractiveness classes from A to $\mathrm{F}$ and resulted in 277 local regions in the final sample with assumed 95\% level of confidence parameter and 5.5\% level of expected error rate. Details of the sample used in the research are presented in table 1.

Table 1. Research sample

\begin{tabular}{|l|c|c|}
\hline $\begin{array}{c}\text { Potential Investment } \\
\text { Attractiveness Class } \\
\text { (from A to F) }\end{array}$ & $\begin{array}{c}\text { Total subpopulation of local regions } \\
\text { within the Potential Investment } \\
\text { Attractiveness Class for 31 December }\end{array}$ & $\begin{array}{c}\text { Final sample of local regions } \\
\text { reflecting the Potential Investment } \\
\text { Attractiveness, assumed level of } \\
\text { confidence and expected error rate }\end{array}$ \\
\hline A & 419 & 44 \\
\hline B & 229 & 13 \\
\hline C & 414 & 43 \\
\hline D & 585 & 86 \\
\hline E & 513 & 66 \\
\hline F & 319 & 25 \\
\hline Total number of local \\
regions
\end{tabular}

Source: own work

The authors designed the research using both nonreactive and reactive research methods. The basic nonreactive research method was the electronic audit of the official web portals of local regions. The tool used for the electronic audit method was a structured questionnaire consisting of 42 questions grouped in thematic blocks focused on communication of local region with the investor and entrepreneur, local region's investment offer, and local region's investment incentives. The basic objective of the electronic audit was the identification and classification of the content in the official web portal of local regions which could be useful for a potential investor or entrepreneur. The electronic audit of all 277 local regions with the use of a standardised set of questions and unified method of coding of answers was performed between 13 July 2017 and 18 August 2017.

In the context of researching activities of local regions, among the reactive research methods the authors decided to use the mystery stakeholder approach (Czerwiński and Krzesaj, 2012). The tool used for the mystery stakeholder approach was 
electronic correspondence prepared from the position of a potential investor, which was sent from an electronic account created for research purposes to official electronic correspondence addresses of local regions in the research sample. The prepared correspondence consisted of short introduction justifying the contact and five questions related to new business activity set up in the local region and related availability of investment infrastructure, investment incentives and support for investors. The mystery stakeholder research of all 277 local regions with the use of standardised correspondence and unified method of coding of answers was performed between 1 August 2017 and 24 August 2017. As 92 out of 277 local regions responded to the mystery stakeholder communication received, the response rate in the mystery stakeholder method research was $33.2 \%$ and the received answers were coded.

The electronic audit research and mystery stakeholder research were complemented with the electronic survey sent to official administrative representatives of the local regions in the sample. The electronic survey consisted of five questions related to

Figure 1. Sampling frame, research sample and methods used in the research

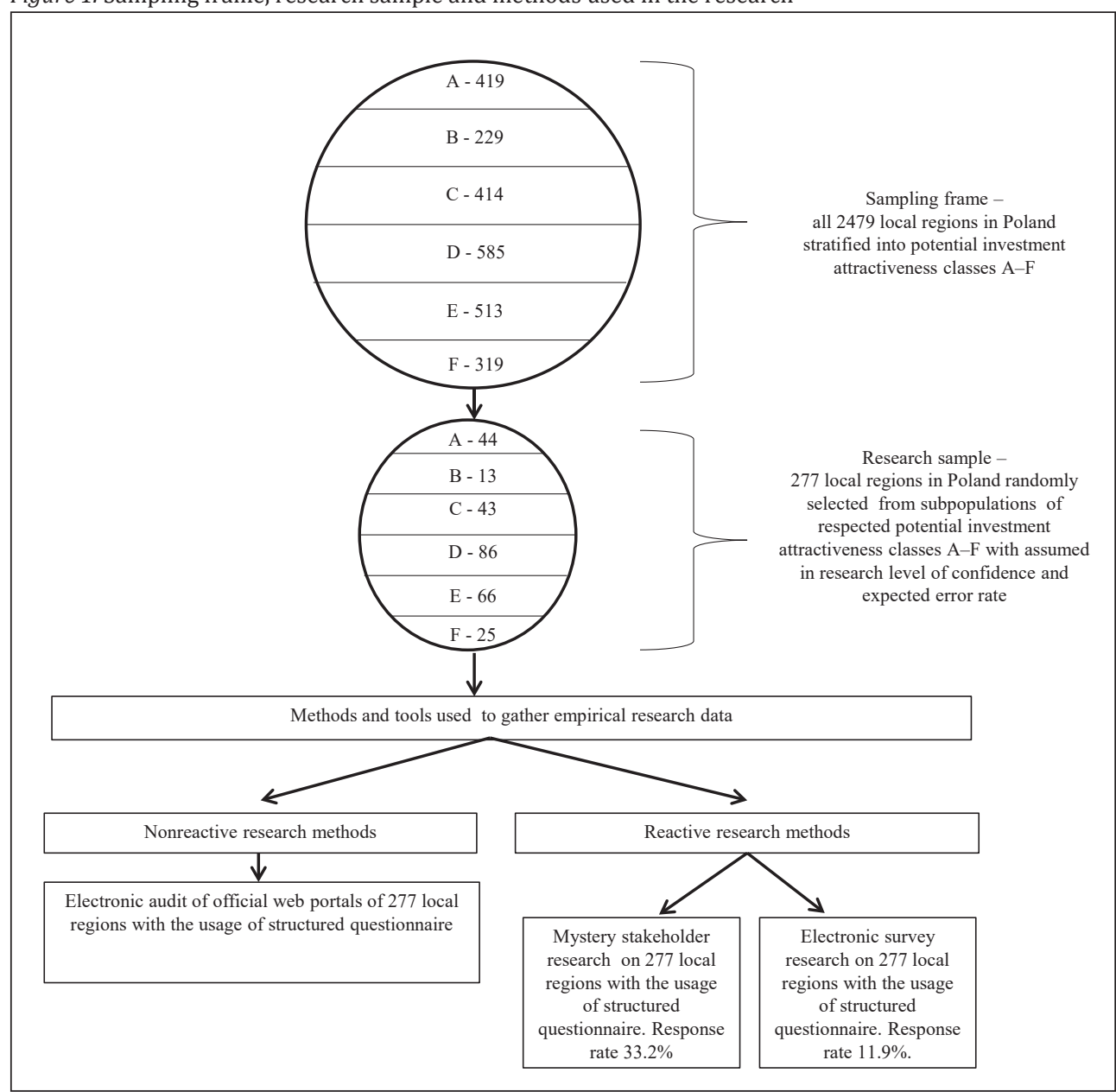

Source: own work 
a subjective perception of attractiveness of investment offer of local region, approach toward decrease of costs of new business activity set up and factors important in attracting new investors to the local region. The electronic survey research of all 277 local regions with the use of a standardised electronic survey questionnaire and unified method of coding of the answers was performed between 27 July 2017 and 31 August 2017. Among 277 local regions research representatives, 33 of them sent filled questionnaires adding up to 66 correctly filled questionnaire pages. The response rate in the electronic survey method was $11.9 \%$ and the received answers were coded respectively. The empirical research data gathered with the use of the above-mentioned methods and tools was analysed with the use of both quantitative and qualitative data analysis methods, including Statistica software version 13.1. The sampling frame, research sample and methods used in the research are presented in Figure 1.

\section{INVESTMENT OFFER OF LOCAL GOVERNMENTS AS AN EXPRESSION OF THEIR MARKETING ORIENTATION}

Generally speaking, market orientation means adopting a proactive and customer-oriented approach which also considers the conditions of the outside environment (Walker, Brewer, Boyne, Avellaneda, 2011: 708). In the literature of the subject, the term "marketing orientation" (MO) is used interchangeably with the term "market orientation" and "customer orientation" (Kowalik, 2010: 45). By the definition by B.J. Jaworski and A.K. Kohlie (1993, quoted by Kowalik, 2010: 45) "market orientation consists in collecting information about the market, particularly about current and future customer needs, transmitting this information to all the cells of the organisation, and then reacting to this information". The approach proposed by B.J. Jaworski and A.K. Kohli (1990) is the most widely cited in the literature of the subject and used in numerous scientific studies due to its practical scale of measurement of the market orientation, i.e. the so-called MARKOR (Kowalik, 2010: 51). This scale is based on 20 items which are used to assess the level of market orientation.

A different approach to the market orientation, though leading to similar observations, was proposed by J.C. Narver and S.F. Slater (1990). Defining market orientation, the authors indicated its three behavioural components, namely customer orientation, competitor orientation, and inter-functional coordination, as well as two additional decision criteria, i.e. profitability and long-term focus (Narver, Slater, 1990: 21-22). For measuring market orientation, the authors have developed a 14item MKTOR scale.

The MARKOR method proposed by Jaworski and Kohli was first adapted and used to measure market orientation in the public sector in Spain (Carver, Molla, Sanchez, 2001) and in Australia (Caruana, Ramaseshan, Ewing, 1998). An interesting approach to the measurement of market orientation in public sector organisations, also based on Jaworski and Kohli's approach, was applied by Portuguese researchers A.P. Rodrigues and J.C. Pinho (2011). The authors assessed the market orientation of public organisations in two dimensions: external and internal. In Poland, the research on market orientation of local governments using the MARKOR scale was conducted by I. Kowalik $(2010 ; 2011)$. The study of market/marketing orientation, though using other methods of measurement, and, to a lesser extent, on Polish grounds, were also dealt with by A. Szromnik (2008) - marketing orientation of cities, K. Borodako (2006) 
- promotion and information activities of poviats, and W. Kuźniar (2013) - marketing activity of gminas.

At present, in Poland, territorial units of all levels acknowledge marketing orientation to some extent (Szromnik, 2006; Kowalik, 2010; 2011). They are aware of the need for marketing activities, but they do not use all available tools. The main barrier is the lack of knowledge of concepts, methods and marketing tools. Still, for many people marketing is poorly understood and is only identified with advertising or promotion.

Undoubtedly, the most important impact tool, indicated in almost all marketing-mix concepts, is the product. As indicated by Holloway and Robinson (1997), properly tailoring the product to market needs is the most important marketing task. Therefore, the success of the product is determined by its attractiveness and competitiveness, and by being adapted to the needs and expectations of customers.

Territorial marketing refers to a product as "territorial product", "municipal product", "regional product", "product of the area", and "product of the region, municipality, town or village". Generally speaking, "products" of cities, villages and regions are defined as utility collections offered as paid, partially paid or unpaid, on various financial, temporal and legal terms, to the "customer" groups (Szromnik, 2008: 116). According to the author of this definition, these utility collections are the main resources of a given territorial unit offered to different groups of customers (Szromnik, 2008: 121).

More and more often, following the formulation introduced years ago by T. Markowski (Szromnik, 2008: 115), the so-called "mega-product" is mentioned - a complex, territorial product, representing the sum/combination of territorial sub-products (such as investment, cultural-educational, convention, trade and service, tourism sub-product, etc.).

The above-presented knowledge allows us to formulate conclusions and accept the investment offer as an investment sub-product, a specific set of utilities offered to interested buyer groups, i.e. entrepreneurs, investors and other entities, such as banks, investment funds, business associations or chambers of commerce (Szromnik, 1997: 41-42).

This investment sub-product consists of: machinery, devices, premises, technological lines, buildings, plots, agricultural land, labour force - labour market resources, technologies, mineral resources, legislation (financial and tax-related), ecological regulations, organisational status of trade unions and their attitudes (Szromnik, 1997: 41-42; Szromnik, 2008: 121).

The above-presented list includes the elements objectively constituting the socalled investment product of a given spatial-administrative unit. In addition to the list of the above-mentioned elements, it would be useful to point out the elements of the offer that a given territorial unit may additionally create, e.g. the level of investor service, the availability of information on the local market for investors, the image of the local region as an attractive place to conduct business activity. Table 2 attempts to systematise these elements and suggests the structure of the investment offer of a commune.

Not all elements are relevant for every investor. The importance of particular elements of the territorial offer depends on the industry, scope and subject of the conducted or potential business activity. 
Table 2. Investment offer of a local government

\begin{tabular}{|c|c|c|c|c|c|}
\hline \multicolumn{6}{|c|}{ Investment offer of a local government } \\
\hline $\begin{array}{l}\text { Natural } \\
\text { resources }\end{array}$ & $\begin{array}{l}\text { Labour market } \\
\text { resources }\end{array}$ & Infrastructure & $\begin{array}{l}\text { Real estate } \\
\text { investment }\end{array}$ & $\begin{array}{l}\text { Legal and } \\
\text { strategic } \\
\text { regulations }\end{array}$ & $\begin{array}{c}\text { Elements related } \\
\text { to market } \\
\text { communication } \\
\text { and investor } \\
\text { services }\end{array}$ \\
\hline $\begin{array}{l}- \text { mineral } \\
\text { resources } \\
\text { - location of } \\
\text { the local } \\
\text { region }\end{array}$ & $\begin{array}{l}\text { - availability of } \\
\text { qualified staff } \\
\text { - attitude/ } \\
\text { mentality } \\
\text { of local } \\
\text { population }\end{array}$ & $\begin{array}{l}\text { - transportation - } \\
\text { state of roads } \\
\text { - technical: } \\
\text { technological } \\
\text { lines, technology } \\
\text { availability, } \\
\text { machinery, } \\
\text { equipment }\end{array}$ & $\begin{array}{l}\text { - land, plots, } \\
\text { - premises, } \\
\text { buildings }\end{array}$ & 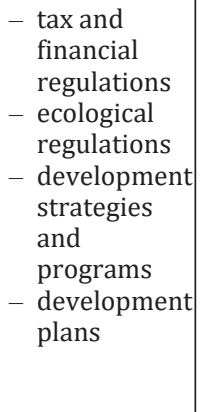 & 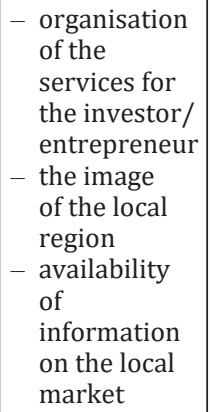 \\
\hline
\end{tabular}

Source: own work based on Szromnik (1997: 41-42), Szromnik (2008: 121)

\section{ACTIVITIES OF LOCAL GOVERNMENT IN CREATION OF INVESTMENT OFFER}

The entity largely responsible for shaping the investment offer of a given spatial-administrative unit in Poland is the local government. In this paper, local governments have been considered, as they have the most real opportunities for actions related to shaping the territorial offer, including investment. However, it should be emphasised, not all components of the investment offer of the local government are the responsibility of local authorities. Local government is responsible for the whole of the issues related to current and future needs of the local community, for forecasting of development directions, tendencies, development barriers, prevention of barriers formation, as well as creation of cooperation system between local actors (Kożuch, 2011: 16). To verify the research hypothesis, the most important are activities which are undertaken with regard to investors - above mentioned and explained investment offer. Local authorities have been obliged by the act of law to perform a group of tasks, appointed to self-dependent performance of public tasks. From the authors' point of view, the most important seems to be aiming at programming, implementation of local development in the context of entrepreneurship. Pursuant to the Act on Commune Self-government, one of the duties of the local authorities is to promote the local region. The attempt to define the areas of activity of local government in the scope of shaping their investment offer is included in Table 3. The actions are divided into those resulting directly from the Act on local self-government and those which lie to a large extent in the area of the invention of local government.

It is important to mention that the changing conditions, including expectations of the buyers - investors, require continual verification and improvement of the territorial investment offer. We are aware that what has been presented here does not exhaust the collection of all possible actions of the municipality in terms of creating an investment offer. Nevertheless, the proposed lists provide a starting point for identifying the set of actions necessary to create a competitive regional investment offer. 
Table 3. Areas of activity of local government in the scope of shaping their investment offer

\begin{tabular}{|c|c|c|}
\hline \multirow{2}{*}{$\begin{array}{l}\text { Components } \\
\text { of the investment offer }\end{array}$} & \multicolumn{2}{|c|}{ Activities of local government } \\
\hline & Obligatory & Facultative \\
\hline $\begin{array}{l}\text { Natural resources: } \\
\text { - mineral resources } \\
\text { - location of the commune }\end{array}$ & - protection and rational use & $\begin{array}{l}\text { - identification of the competitive } \\
\text { advantage of the local region } \\
\text { resulting from the location or } \\
\text { possessed natural resources }\end{array}$ \\
\hline $\begin{array}{l}\text { Labour market resources } \\
\text { - availability of qualified staff } \\
\text { - attitude/mentality of local } \\
\text { population }\end{array}$ & $\begin{array}{l}\text { - issues of support } \\
\text { and dissemination of } \\
\text { selfgovernment ideas, } \\
\text { including the creation of } \\
\text { conditions for the operation } \\
\text { and development of support } \\
\text { units and the implementation } \\
\text { of civic participation } \\
\text { programs }\end{array}$ & $\begin{array}{l}\text { - shaping attitudes and } \\
\text { entrepreneurial behaviours } \\
\text { among citizens through, for } \\
\text { example, organising training or } \\
\text { using tools for marketing ideas } \\
\text { - intermediation between } \\
\text { employers expressing } \\
\text { demand for workers and } \\
\text { workers expressing supply } \\
\text { of work at a local workplace } \\
\text { - e.g. organisation of labour } \\
\text { exchanges }\end{array}$ \\
\hline $\begin{array}{l}\text { Infrastructure } \\
\text { - transportation - state of roads } \\
\text { - technical: technological } \\
\text { lines, technology availability, } \\
\text { machinery, equipment }\end{array}$ & $\begin{array}{l}\text { - matters of local region roads, } \\
\text { streets, bridges, squares and } \\
\text { road traffic } \\
\text { - telecommunications } \\
\text { activities } \\
\text { - communal, electric and } \\
\text { heating infrastructure }\end{array}$ & $\begin{array}{l}\text { - designation of parking zones } \\
\text { (redundancies in the parking } \\
\text { area for the investor) }\end{array}$ \\
\hline $\begin{array}{l}\text { Real estate investment } \\
\text { - land, plots, } \\
\text { - premises, buildings }\end{array}$ & $\begin{array}{l}\text { - fair and market issues } \\
\text { - matters of community } \\
\text { greenery and tree planting }\end{array}$ & $\begin{array}{l}\text { - actions for the preparation of } \\
\text { real estate (land/premises) of } \\
\text { local region for investment } \\
\text { - coworking infrastructure } \\
\text { - identifying and offering or } \\
\text { mediating in the offering } \\
\text { of infrastructure enabling } \\
\text { establishment and running } \\
\text { of business in the form of } \\
\text { purchase, lease, letting, or in } \\
\text { another legal form }\end{array}$ \\
\hline $\begin{array}{l}\text { Legal and strategic regulations } \\
\text { - tax and financial regulations } \\
\text { - ecological regulations } \\
\text { - development strategies and } \\
\text { programs } \\
\text { - development plans }\end{array}$ & $\begin{array}{l}\text { - adopting resolutions on taxes } \\
\text { and fees within the limits } \\
\text { specified in separate acts } \\
\text { - development and adoption of } \\
\text { economic and development } \\
\text { programs } \\
\text { - conducting feasibility studies } \\
\text { and directions of spatial } \\
\text { development of the local } \\
\text { region and local spatial } \\
\text { development plans }\end{array}$ & $\begin{array}{l}\text { - creation - based on local } \\
\text { regulations - of special } \\
\text { economic activity zones and } \\
\text { special economic areas with } \\
\text { local investment incentives for } \\
\text { investors and entrepreneurs } \\
\text { - the introduction of } \\
\text { nonstatutory exemptions in } \\
\text { local fees, real estate taxes and } \\
\text { others. } \\
\text { - assessment and analysis of the } \\
\text { current situation in relation to } \\
\text { the needs of the local spatial } \\
\text { development plan } \\
\text { - introduction of proecological } \\
\text { benefits }\end{array}$ \\
\hline $\begin{array}{l}\text { Elements related to market } \\
\text { communication and investor } \\
\text { services } \\
\text { - organisation of the services for } \\
\text { the investor/entrepreneur }\end{array}$ & $\begin{array}{l}\text { - promotion of the local } \\
\text { region } \\
\text { - adopting resolutions in } \\
\text { matters of the coat of arms of } \\
\text { the local region }\end{array}$ & $\begin{array}{l}\text { - organisation/creation of a unit } \\
\text { dedicated to serve the investor } \\
\text { - creation of a local information } \\
\text { exchange system between } \\
\text { companies/investors }\end{array}$ \\
\hline
\end{tabular}




\begin{tabular}{|c|c|c|}
\hline $\begin{array}{l}\text { - the image of the local region } \\
\text { - availability of information on the } \\
\text { local market }\end{array}$ & $\begin{array}{l}\text { - granting the honorary } \\
\text { citizenship of the local region } \\
\text { - organisation and functioning } \\
\text { of the municipality office and } \\
\text { auxiliary units }\end{array}$ & $\begin{array}{l}\text { - providing/publishing } \\
\text { information on the local market } \\
\text { on the local region website (e.g. } \\
\text { information on the number and } \\
\text { structure of business entities } \\
\text { operating in the local region, } \\
\text { size and qualifications of the } \\
\text { local staff) } \\
\text { - providing/publishing on } \\
\text { the local region website } \\
\text { information on the availability } \\
\text { of real estate (i.e. land, } \\
\text { premises, whole buildings) for } \\
\text { investment } \\
\text { - introduction of the possibility } \\
\text { of paying taxes and charges } \\
\text { electronically } \\
\text { - building the image of the local } \\
\text { region as an attractive place to } \\
\text { do business }\end{array}$ \\
\hline
\end{tabular}

Source: own work based on Szromnik (1997: 41-42), Szromnik (2008: 121) and the Act of March 8, 1990 on municipal self-government, Journal of Laws, no. 1990 No. 16 pos. 95

\section{MARKETING APPROACH OF LOCAL GOVERNMENT IN THE CONTEXT OF THEIR INVESTMENT ATTRACTIVENESS}

Within electronic audit research we have investigated premises demonstrating that local region use MO in its activities toward attracting entrepreneurs, investors, inhabitants and tourists. One of such premises was brand promise of spatial unit understood as a guarantee of certain values or benefits related to the defined place and demonstrated through communication in official electronic portal of local region. Brand promises of spatial units deliberately create and strengthen perception of a place and can focus on the uniqueness of location, living infrastructure, natural environment, cultural spirit and other dimensions. They are also clear indicator of following MO by local governments as brand promise directly relates to territorial product spatial unit offers (Naipau, Wang, Okumus, 2009: 462).

In our research sample over $16 \%$ of all 277 local regions investigated had official brand promise they communicated through their official websites. Examples identified referring to above-mentioned aspect of MO included, among others: Będzin - "On the Top", Łaziska Górne - "City of Broad Perspectives", Nowa Sól - "On the Flow", Milanówek - "Garden City", Olsztynek - "One Visit is not Enough", Polkowice - "Local Region for the Future", Paczków - "Polish Carcassonne", Szczecinek - "Hundreds of Years, Thousands of Possibilities", or Węgrowiec - "Ignites Energy". The highest percentage of local regions having and communicating their brand was identified among local regions with high PAI indicator and declined systematically with level of PAI represented by local regions. We present the details in Figure 2.

Another premise of MO of local regions that we have researched through electronic audit was the easiness of making potential contact with representatives of local government from the perspective of an entrepreneur or investor. In order to identify, qualify and measure that aspect we were searching for contact data or contact form to a person or a department responsible for entrepreneurs on the official website of a local region. Almost $52 \%$ of 277 local regions investigated demonstrated the availability of 
Figure 2. Percentage of local regions from the research sample with official brand promise communicated through their official website and their PAI (class A-B - high, class C-D - medium, class E-F - low)

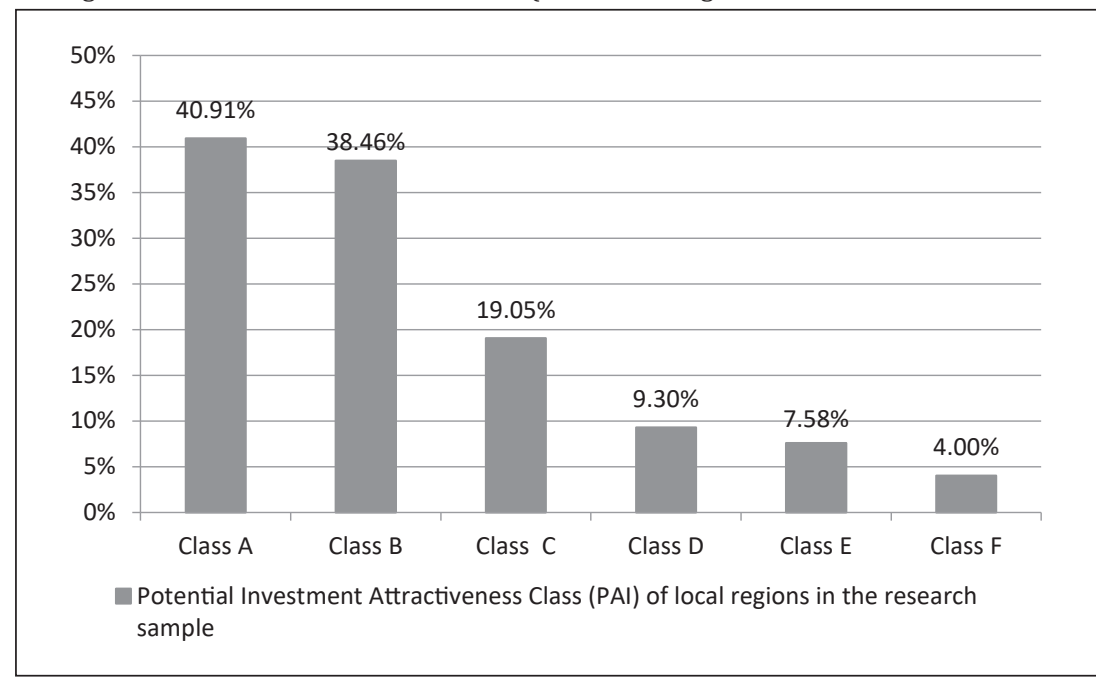

Source: own work based on research performed

Figure 3. Percentage of local regions from the research sample with contact details or contact form to department or person responsible for contacts with entrepreneurs and investors communicated through their official website and their PAI (class A-B - high, class C-D - medium, class E-F - low)

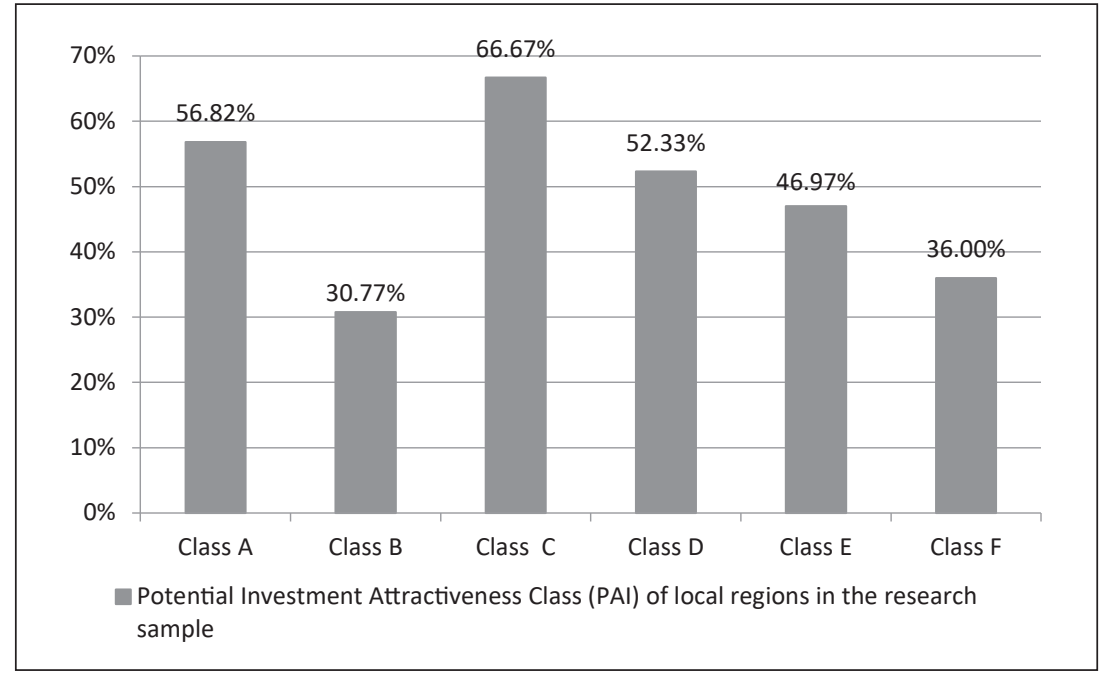

Source: own work based on research performed

the above-described aspect. Surprisingly these were local regions with PAI of medium class (class $\mathrm{C}-\mathrm{D}$ ), which were the most open and encouraging to making official contact with the intensity - on average $59 \%$ of local regions in class C-D in relation to the size of their subpopulation in the research sample. The second highest rated classes of local regions were these with highest PAI (class A-B) with average demonstration of searched phenomena at $44 \%$ level, and the last were local regions with the lowest PAI (class E-F) 
demonstrating openness and encouraging toward making contact at on average 41\% level with respect to sizes of adequate subpopulations in the research sample. Details are presented in Figure 3.

We have deepened aspects of openness and easiness of making contact by entrepreneurs and investors with local governments and investigated it through structured questionnaire in the form of an electronic survey with local governments' representatives. It appeared that on average almost $13 \%$ of local regions with PAI of A-B holds dedicated person within organisational structures responsible for contacts and services for entrepreneurs and investors, whereas in both local regions of C-D and E-F classes of PAI it was $3.5 \%$. Having a dedicated person responsible for nurturing contacts with entrepreneurs and investors might require additional effort or resources and exceeds legal obligation of local regions. Therefore, we classify this as clear demonstration of EA of local government.

Through another research method used, mystery stakeholder research, we received empirical data enabling to measure the willingness of local government to support the formation of new economic activity. On average $21 \%$ of local regions with PAI of A-B offered this form of support, whereas in the case of local regions of $\mathrm{C}-\mathrm{D}$ and $\mathrm{E}-\mathrm{F}$ classes of PAI it was respectively on average $14 \%$ and $11 \%$ of spatial units within subpopulations of classes in the sample.

Additional aspects related to communication and elimination of asymmetry of information useful for entrepreneurs, investors, inhabitants and tourists were researched with particular attention to dedicated institutions structured by local government with the purpose to maintain continuous dialogue with entrepreneurs and investors. Forms of these institutions were researched by us through the electronic audit method and included recurring local-economy-oriented meetings with local government, activity of local economic associations, and local economic supported by local governments and also organisation of recurring events led by local government with and for entrepreneurs and investors (e.g. focused on the spreading of know-how and best practices). These type of activity were demonstrated by nearly $6 \%$ of 277 local regions researched. On average there were $21 \%$ of A-B class of PAI local regions within A-B subpopulation in the sample which demonstrated these type of activities, whereas for C-D and E-F classes of PAI it was respectively $3.5 \%$ and $2 \%$ of local regions. In the context of facilitation of economic opportunity by local governments, only small percentage of all local regions researched ( $6 \%$ out of 277 local regions) informed through their official websites about fairs, events, travels, visits enabling entrepreneurs and investors presentation and promotion of their offer. Investigation of these phenomena related to research of available for the moment of research and archived main pages of official websites of local regions. Low level of this type of information in the context of globalising markets and hyper communication might seem unsatisfying.

Presented aspects of MO and EA resulting from our research are of particular importance due to other studies which indicate that the quality of communication between public sector managers and local region's stakeholders impacts the perception of quality of life and benefits the spatial unit offers. Van der Meer and Van Winden indicate modern toolkits of local region's communication: local TVs, payment systems, but also personal computers, laptops, and mobile devices. Although modern technology might facilitate communication between local government and stakeholders of location, it will not replace a human being the spiritus movens of entrepreneurial activities (Van der Meer, Van Winden, 2003: 408). 


\section{INVESTMENT OFFER OF POLISH LOCAL GOVERNMENT IN THE CONTEXT OF THEIR INVESTMENT ATTRACTIVENESS}

Perceiving the investment offer (IO) as an investment sub-product (understood as a set of useful benefits offered to entrepreneurs and investors, and which we have already defined in detail) directed our attention to local real estate market. The development of the real estate market determines the development of the entire economy and affects the prospects for further economic development (Zaremba, 2011: 115). In our research sample 21\% investigated local regions informed potential partners about properties located there. Every fifth local region communicated through their official websites the offer including properties intended to rent, sale or lease for investment purposes. Moreover, in individual cases one can find the offer only for residential development, one offer considered plots for detached houses and $2 \%$ of local regions prepare the offer concerning tenders (dwellings, land for agricultural purposes, all plots). In the context of potential attractiveness classes (PAI), the availability of information about the real estate market oscillates in whole classes at around $22 \%$ (except class D). The investigation shows that regardless of the represented class they had similar percentage in this offering (Figure 4).

Researching IO as usable benefits offered to the groups of purchasers we also refer to the co-working space. We are conscious of differences between spatial units (features of the local regions - city, or rural local regions) but we have looked at this issue through the prism of fundamentally changing working philosophy in modern economies. We noticed communicating available co-working spaces through official website of local regions as important because of key role of that places in self-employed professionals and small businesses at an early stage of their development. It is also influenced by that the start-up of many world-class companies starting with the lease of a few desks in one of the shared offices.

Figure 4. Percentage of local regions from the research sample with real estate market communicated through their official website and their PAI (class A-B - high, class C-D - medium, class E-F - low)

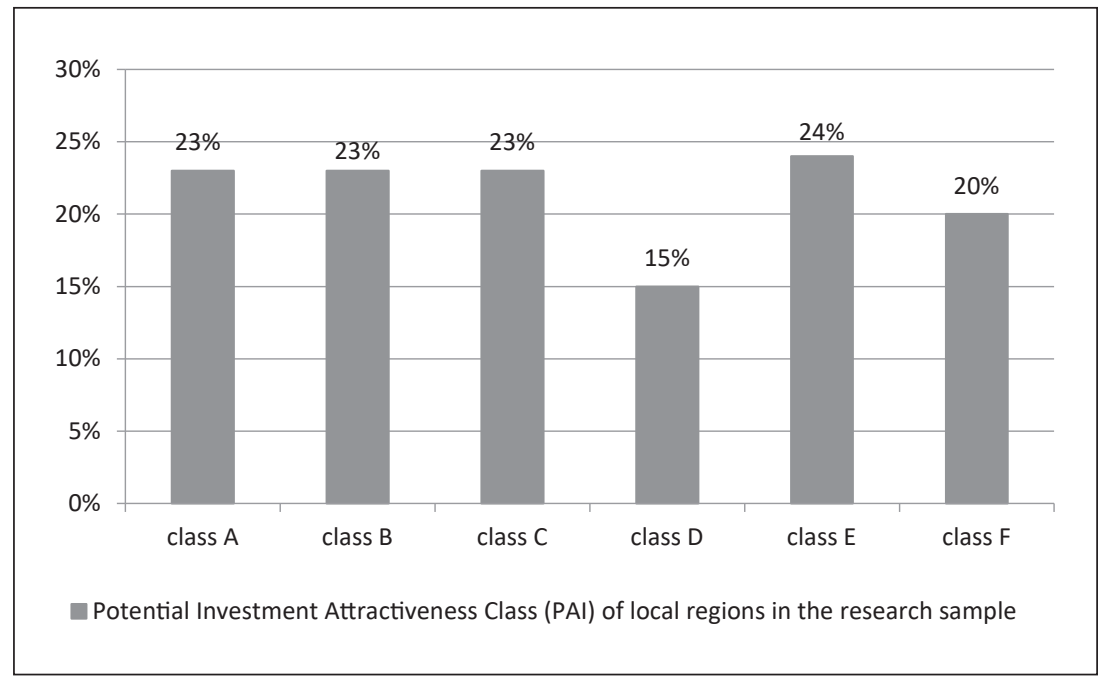

Source: own work based on research performed 
In our research sample only $3 \%$ investigated local regions informed potential partners through their official website about available co-working space for entrepreneurs. The investigations show that only local regions from class $\mathrm{A}, \mathrm{E}$ and $\mathrm{F}$ have this information on their website. They represent $9 \%$ of investigated local regions from class A, 3\% of investigated local regions from class $\mathrm{E}$, and $12 \%$ of investigated local regions from class F. Moreover, 2 local regions offer conference spaces and 2 common rooms. After quantitative analysis of this issue we conclude that it is not directly related to the PAI of local regions.

In order to explore the investment attractiveness of local governments we analysed the investment offer (IO) in the official electronic portal of local regions. At the beginning of our research we focused on checking the general information concerning the investment advantages, i.e. the availability of economic characteristics of the local region with special prominence why it is worth to invest in particular local region. Nearly $62 \%$ of 277 analysed local regions had this kind of information on its official Internet websites. Unexpectedly, the highest percentage of local regions with information about why it is worth to invest in was noted in class C (medium) and F (with lowest PAI ). Details are presented in Figure 5.

We have also checked if on local region official website a brochure or video with general advantages for investment in the local region is available for downloading. Unfortunately, only $13.72 \%$ of 277 examined local regions had at least one of the downloadable materials. According to data in Figure 6, the highest score was achieved by the local regions representing class A, B and C (with high PAI) and the worst situation was in local regions with the lowest PAI (class F) - with no brochures or videos available for download. The leaders ( $2.5 \%$ of researched objects) of local regions in this feature, that had two or more of this kinds of materials are the following local regions: Łobez (with investment offer prepared in Polish, English, German and Russian language version

Figure 5. Percentage of local regions from the research sample with general information concerning the investment advantages through their official website and their PAI (class A-B - high, class C-D - medium, class E-F - low)

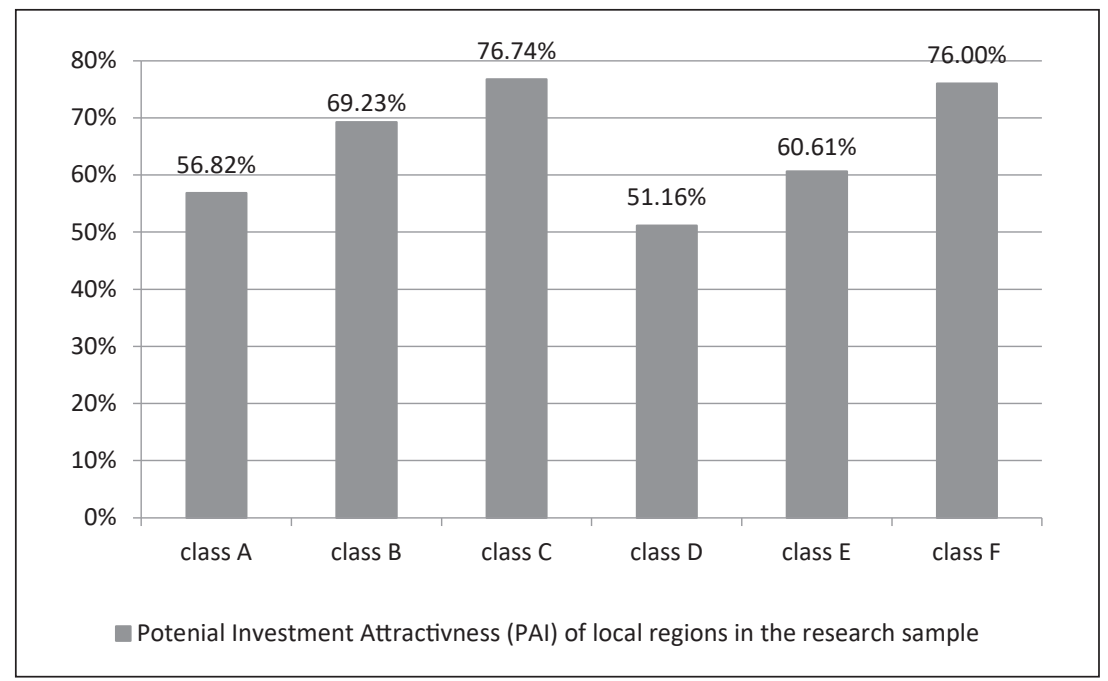

Source: own work based on research performed 
and virtual walk), Łuków (with a film in Polish and English); Dobrzeń Wielki, Solina (with promotion film), Teresin (with presentation about the local region and detailed investment brochure), Koronowo (film in Polish about investment offer), and Lipnik (brochure in Polish and English concerning investment offer).

Figure 6. Percentage of local regions from the research sample with the downloadable brochure or video with general advantages for investment through their official website and their PAI (class A-B - high, class C-D medium, class E-F - low)

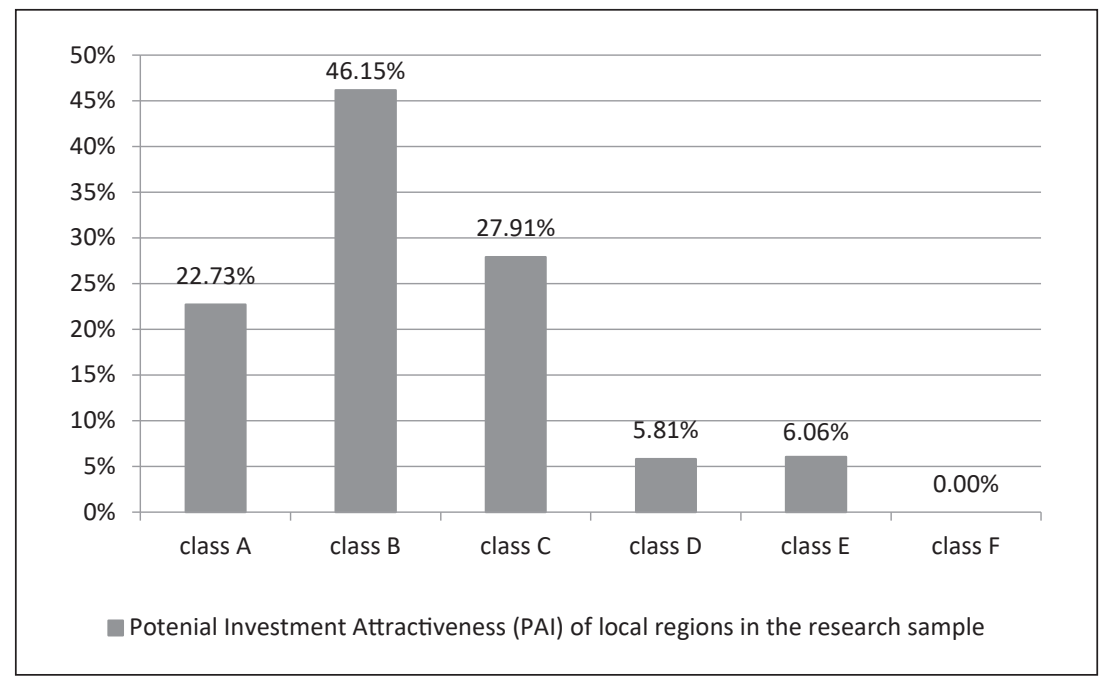

Source: own work based on research performed

Figure 7. Percentage of local regions from the research sample with information regarding a free time offer in local region for investors through their official website and their PAI (class A-B - high, class C-D - medium, class E-F - low)

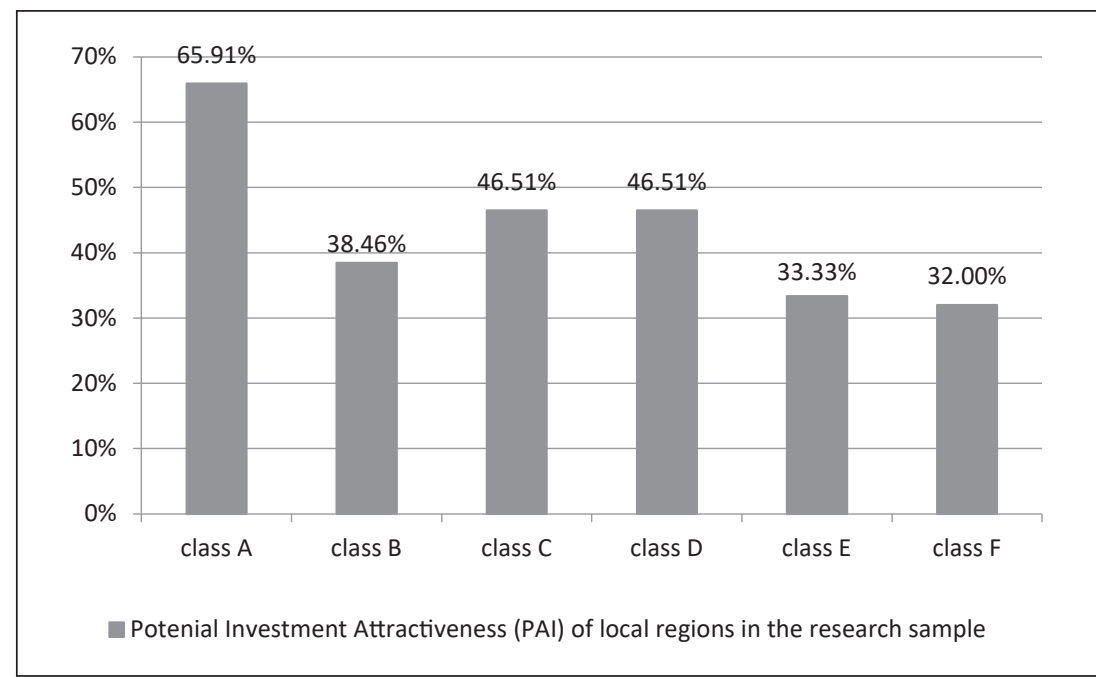

Source: own work based on research performed 
The next aspect that we have investigated in local regions through electronic audit was the availability of information concerning free time offer in local region for entrepreneurs and investors (eg. cultural offer). The highest percentage of local regions having a free time offer was identified among local regions with high PAI indicator (class A) and the lowest percentage in local regions representing the lowest level of PAI (class E, F). The results of this research is presented in Figure 7.

The next step and the second part of our research aimed at exploring the investment offer of Polish local governments in the context of their investment attractiveness was an electronic survey. We have sent a survey to all 277 researched local regions, asking them about how they perceive the attractiveness of their investment offer. Unfortunately only $11.6 \%$ answered, however the study shows that the higher the level of the PAI, the higher the local region's self-assessment of the attractiveness of the investment offer. Approximately $25 \%$ of local regions with high PAI (representing class A-B) considered their investment offer distinctive and highly competitive. An argument for such a response was the localisation of the special economic zone in the local region, the use of relief for potential investors and the realisation of investments aimed at improving the quality of life of the inhabitants, as well as attractive and fully equipped investment areas in the direct locality of the motorway exit. Roughly 3.7\% of local regions stated that their investment attractiveness is poor in areas that can serve investment, and there is an urgent need to designate such areas in the local plans and adapt them for investment needs.

\section{CONCLUSIONS}

The marketing concept of the functioning of territorial units is well-known today, both in the literature of the subject and in practice, although the activities undertaken vary in their intensity and scope. The expressions of marketing thinking and actions are, among other things, activities undertaken by local governments in the area of shaping the offer of a territorial unit. In our research, we focused on the territorial investment offer (in the territorial marketing jargon also referred to as the territorial investment sub-product) of the Polish local regions (NUTS 5), as well as actions taken by local governments as the entities with the most real opportunities for shaping this offer. As a result of our analyses, we identified two types of activities in this area: obligatory and facultative. We have indicated that obligatory actions stem from the Local Government Act, while facultative activities result from the invention, entrepreneurship and marketing approach of the local government.

The research allowed us to achieve the objective of the main study, which was the exploration of MO and IO in the practice of local governments, and then attempt to link the above-mentioned practices with their potential investment attractiveness (PAI). We initially assumed that local MO and IO activities would correspond to their PAI, in the sense that they would have the highest intensity in the regions with the highest PAI. Generally speaking, this assumption was not reflected in the research conducted, and not always local regions with the highest PAI demonstrated the highest intensity of action, whether within MO or IO. It should be noted, however, that these studies were conducted with the use of three research methods: electronic audit of the official web portals of local regions, the mystery stakeholder, and an electronic survey sent to the official administrative representatives of the local regions in the sample. Taking into 
account the above-described, we have found that the assumed correlation (i.e. the higher the PAI, the higher the intensity of action) occurs in studies using reactive methods (i.e. mystery stakeholder and electronic survey). One limitation to the wider reasoning behind them is that in both methods we have a relatively low number of returned questionnaires.

In conclusion, the conducted research shows that Polish local governments are slowly adopting MO, increasingly identifying their customers (including investors) and knowingly providing the expected benefits. Nevertheless, we have noticed that particular strengthening and intensification should be aimed at leading and deepening the ongoing dialogue of local governments with investors/entrepreneurs, which in the face of globalising markets and hyper-communication seems particularly important. In this aspect, not only the widespread use of IT tools, but also the role of the human factor seem to be important. It is crucial to remember that this factor is always key to building lasting relationships with the client, and the activity and entrepreneurship of the local region depends on the activity and entrepreneurship of people who are employed in local government units and hold management functions. As part of the conducted research we have gathered a wide collection of good practices in the area of shaping the investment offer and marketing approach which should be promoted and discussed.

In order to develop and complement our research, we recommend taking into account the longer period in which these studies would be conducted, as well as extending the research sample, particularly regarding reactive research in order to achieve greater representativeness. In our opinion, the problem of $\mathrm{MO}$ of local government requires further exploration especially in terms of IO structure and use of other marketing tools.

\section{Acknowledgement}

Research tools designed by us prior to data gathering phase have been consulted and included remarks received from representatives of Polish Investment and Trade Agency (PAIH). Authors express gratitude for time and attention given by representatives of PAIH in the planning phase of our research project.

\section{References}

Area and population in the territorial profile in 2016 (2016). Warsaw: Central Statistical Office.

Borodako, K. (2006). Działalność promocyjno-informacyjna polskich powiatów w kontekście wspierania przedsiębiorczości na podstawie badań bezpośrednich. Samorząd Terytorialny, 4, 28-40.

Caruana, A., Ramaseshan, B., Ewing, M.T. (1997). Market orientation and organizational commitment in the Australian public sector. International Journal of Public Sector Management, 10(4), 294-303.

Carver, A., Molla, A., Sanchez, M. (2001). Antecedents and consequences of market orientation in public organizations. European Journal of Marketing, 35, 11-12.

Czerwiński, A., Krzesaj, M. (2012). Wykorzystanie analizy korespondencji do badania internetowej aktywności informacyjnej przedsiębiorstw w biznesie internetowym [Usage of correspondence analysis in internet research of information activities of enterprises in internet business]. W: S. Forlicz (red.). Zastosowanie metod ilościowych $w$ ekonomii i zarządzaniu [Usage of quantitative methods in economics and management]. Warszawa: CeDeWu.

Godlewska-Majkowska, H. (red.) (2011). Atrakcyjność inwestycyjna a przedsiębiorczość regionalna $w$ Polsce [Investment attractiveness and regional entrepreneurship in Poland]. Warszawa: Oficyna Wydawnicza Szkoła Główna Handlowa. 
Godlewska-Majkowska, H. (red.) (2013). Atrakcyjność inwestycyjna regionów Polski na tle Unii Europejskiej [Investment attractiveness of Polish regions in European Union]. Warszawa: Oficyna Wydawnicza Szkoła Główna Handlowa.

Holloway, J.Ch., Robinson, Ch. (1997). Marketing w turystyce [Marketing in tourism]. Warszawa: Polskie Wydawnictwa Ekonomiczne.

Jaworski, B.J., Kohli, A.K. (1993). Market orientation: Antecedents and Consequences, Journal of Marketing, 57, 53-70.

Kohli, A.K., Jaworski, B.J. (1990). Market Orientation: The Construct, Research Propositions, and Managerial Implications. Journal of Marketing 54(2), 1-18.

Kotler, Ph., Rein, I.J., Haider, D. (1999). Marketing Places Europe: How to Attract Investments, Industries, Residents and Visitors to Cities, Communities, Regions and Nations in Europe. London: Financial Times Prentice Hall.

Kowalik, I. (2010). Orientacja rynkowa w polskim samorządzie terytorialnym [Market orientation in the Polish territorial self-government]. Warszawa: Oficyna Wydawnicza Szkoła Główna Handlowa.

Kowalik, I. (2011). Market orientation and its antecedents in the Polish local governments. International Journal of Public Sector Management, 24(1), 57-79.

Kożuch, A. (2011). Rola samorządu terytorialnego we wspieraniu rozwoju lokalnego [The role of territorial self-government in supporting local development]. W: A. Kożuch, A. Noworól (red.). Instrumenty zarządzania rozwojem $w$ przedsiębiorczych gminach [The instruments for development management in entrepreneurial communes]. Kraków: Instytut Spraw Publicznych Uniwersytetu Jagiellońskiego w Krakowie.

Kuźniar, W. (2013). Aktywność marketingowa gmin i jej oddziaływanie na rozwój turystyki wiejskiej [Marketing activity of the communes and its influence on the development of rural tourism]. Rzeszów: Wydawnictwo Uniwersytetu Rzeszowskiego.

Markowski, T. (1999). Zarządzanie rozwojem miast [Urban development management]. Warszawa: Wydawnictwo Naukowe PWN.

Markowski, T. (2006). Marketing miasta [City marketing]. W: T. Markowski (red.). Marketing terytorialny [Territorial marketing], t. CXVI. Warszawa: Komitet Przestrzennego Zagospodarowania Kraju Polskiej Akademii Nauk.

Naipaul, S., Wang, Y., Okumus, F. (2009). Regional destination marketing: a collaborative approach. Journal of Travel and Tourism Marketing, 26, 462-481.

Never, J.C., Slater, S.F. (1990). The Effect of a Market Orientation on Business Profitability. Journal of Marketing, 54(4), 20-35.

Rodriguez, A.P., Pinho, J.C. (2011). The impact of internal and external market orientation on performance in local public organisations. Marketing Intelligence \& Planning, 30(3), 284-306.

Szromnik, A. (1997). Marketing terytorialny - geneza, rynki docelowe i podmioty oddziaływania. W: T. Domański (red.). Marketing terytorialny: strategiczne wyzwania dla miast i regionów. Łódź: Centrum Badań i Studiów Francuskich Uniwersytetu Łódzkiego.

Szromnik, A. (2006). Marketing terytorialny - koncepcja ogólna i doświadczenia praktyczne [Territorial marketing - general concept and practical experience]. W: T. Markowski (red.). Marketing terytorialny [Territorial marketing], t. CXVI, Warszawa: Komitet Przestrzennego Zagospodarowania Kraju Polskiej Akademii Nauk.

Szromnik, A. (2008). Marketing terytorialny. Miasto i region na rynku. Wyd. II. [Territorial marketing - city and region on the market. Second Edition]. Kraków: Wolters Kluwer.

Ustawa z dnia 8 marca 1990 r. o samorządzie gminnym (Dz.U. z 1990 r., nr 16, poz. 95 [Act of March 8, 1990 on municipal self-government, Journal of Laws, no. 1990 No. 16 pos. 95].

Van der Meer, A., Van Winden, W. (2003). E-governance in Cities: A Comparison of Urban Information and Communication Technology Policies. Regional Studies, 37(4), 417-419.

Walker, R.M., Brewer, G.A., Boyne, G.A., Avellaneda, C.N. (2011). Market Orientation and Public Sector Performance: New Public Management Gone Mad? Public Administration Review, 71(5), 707-717.

Zaremba, A. (2011). Uwarunkowania rozwoju rynku nieruchomości jako istotnego czynnika rozwoju lokalnego [Conditions of development of the real estate market as an important factor of local development]. Journal of Agribusiness and Rural Development, 1(19), 115-121. 
Niki Derlukiewicz, Ph.D., assistant professor at the Department of Macroeconomics at the Faculty of Economic Sciences of Wroclaw University of Economics. Her interests include: innovative economy and entrepreneurs, local and regional development, innovation strategies.

\title{
Address:
}

\author{
Wroclaw University of Economics \\ Faculty of Economic Sciences \\ Department of Macroeconomics \\ ul. Komandorska 118/120; 53-345 Wrocław, Poland \\ e-mail: niki.derlukiewicz@ue.wroc.pl
}

Anna Mempel-Śnieżyk, Ph.D., assistant professor at the Department of Spatial Economy and Local Government Administration at the Faculty of Economic Science of Wroclaw University of Economics. Her interests include: clusters, network cooperation, local and regional development.

\section{Address:}

Wroclaw University of Economics

Faculty of Economic Science

Department of Spatial Economy and Local Government Administration

ul. Komandorska 118/120; 53-345 Wrocaw, Poland

e-mail: anna.sniezyk@ue.wroc.pl

Tomasz Pilewicz, Ph.D., assistant professor at the Collegium in Business Administration of Economic Science of Warsaw School of Economics. Professional MBA Entrepreneurship \& Innovation Alumnus. His research interest include: entrepreneurship, local and regional development, investment attractiveness, business location, transaction costs.

\section{Address:}
Warsaw School of Economics
Collegium in Business Administration
ul. Niepodległości 162; 02-554 Warsaw, Poland
e-mail: tomasz.pilewicz@sgh.waw.pl

Małgorzata Zdon-Korzeniowska, Ph.D., assistant professor at the Department of Entrepreneurship and Spatial Management in the Institute of Geography of the Pedagogical University of Cracow. Her research interest include: market orientation of local government, territorial marketing, management of tourism at local and regional level, regional tourism products.

\section{Address:}

Pedagogical University of Cracow

Institute of Geography

Department of Entrepreneurship and Spatial Management

ul. Podchorążych 2, 30-084 Krakow, Poland

e-mail: malgorzata.zdon-korzeniowska@up.krakow.pl 